\title{
Characterization of closed nickel-titanium orthodontic coil springs
}

\author{
T. Langeron ${ }^{1}$, M.P. Filleul ${ }^{1,2}$ and J. Van Humbeeck ${ }^{3}$ \\ ${ }^{1}$ Faculté de Chirurgie Dentaire, Université René Descartes, Paris V, 102 rue Pierre Butin, \\ 95300 Pontoise, France \\ ${ }^{2}$ Laboratoire de Métallurgie Structurale, ENSCP, 75031 Paris, France \\ ${ }^{3}$ Faculteit Toegepaste Wetenschappen, Metaalkunde en Toegepaste Materialkunde, \\ Katholieke Universiteit Leuven, de Croylaan 2, 3001 Heverlee, Belgium
}

\begin{abstract}
Nickel-Titanium orthodontic coil springs are used to move teeth with low forces and slow deactivation. The present paper provides data on transfomation temperatures and on load-deflection rate at buccal temperature of closed Nickel-Titanium coil springs available on the market from $O R M C O^{\star}$ and $\mathrm{GAC}^{\star}$.

All the springs exhibited superelasticity but their properties were not stable in the range of buccal temperatures and varied not only from one manufacturer to the other but they also varied from one batch to the other of each supplier. The need for more stability is stressed.
\end{abstract}

\section{INTRODUCTION}

Coil springs are used in fixed orthodontic appliances as auxiliaries to move a tooth or a group of teeth (figure 1). Originally coil springs were made of stainless steel or cobalt chromium nickel alloys. The use of nickel titanium alloys is the answer to the need of a lower and more constant force during deactivation. These properties are desirable for orthodontic tooth movement.

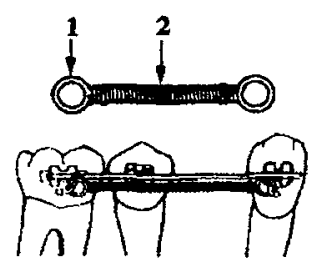

Figure 1: Closed nickel-titanium coil spring.Stainless steel eyelets (1), Ni-Ti coil (2)

The behaviour of a coil spring is usually expressed according to the formula

$$
\mathrm{F}=\mathrm{Gd}^{4} \mathrm{x} / 8 \mathrm{D}^{3} \mathrm{~N}
$$

where $\mathrm{G}$ is the torsional modulus of elasticity, $\mathrm{d}$ the diameter of the wire, $\mathrm{x}$ the displacement, $\mathrm{D}$ the diameter of the coil and $\mathrm{N}$ the number of coils [1].

But the mechanical behaviour of Nickel-Titanium alloys depends on the composition, temperature and strain [2]. The clinician needs available experimental data because the formula not apply to Ni-Ti.

The purpose of this study is to test the performances in tension at buccal temperatures of Nickel-Titanium orthodontic coil springs currently found on the market. 


\section{MATERIAL}

Samples were drawn at random from batches of Nickel-Titanium coil springs also drawn at random from two batches provided by two firms retailing orthodontic materials.

$\mathrm{ORMCO}^{\oplus}$ coil springs (Ref. ORO 2225610, light force): batch $\mathrm{n}^{\circ} 7 \mathrm{H} 1$ and batch $\mathrm{n}^{\circ} 7 \mathrm{D1} 2$

$\mathrm{GAC}^{\otimes}$ coil springs (Ref. 10-000-02): batch $n^{\circ} \mathrm{A} 4 \mathrm{Y} 7$ and batch $\mathrm{n}^{\circ} \mathrm{A} 4 \mathrm{X} 7$

\section{METHODS}

3.1 One coil spring from each manufacturer was submitted to Scanning Electron Microscopy (S.E.M.) to determine their composition.

3.2 Transformation temperatures of alloys from which the coil springs are made were established by Differential Scanning Calorimetry (D.S.C.) which includes:

an analysis modulus TA 2920 with a D.S.C. cell,

a cooling system LNCA (liquid Nitrogen Cooling Accessory) allowing cooling to $-150^{\circ} \mathrm{C}$

a PC for thermal analysis (Thermal Analyst Controller TA 2000).

The cooling rate was $\pm 10^{\circ} \mathrm{C} /$ minute, the precision was $0.2 \mu$ watt with a range of temperature from $-150^{\circ} \mathrm{C}$ to $725^{\circ} \mathrm{C}$. Temperature was regulated by Helium.

3 coil springs per batch from $-90^{\circ} \mathrm{C}$ to $100^{\circ} \mathrm{C}$

1 coil spring from $-90^{\circ} \mathrm{C}$ to $100^{\circ} \mathrm{C}$, from $-70^{\circ} \mathrm{C}$ to $100^{\circ} \mathrm{C}$, from $-50^{\circ} \mathrm{C}$ to $100^{\circ} \mathrm{C}$, from $-30^{\circ} \mathrm{C}$ to $100^{\circ} \mathrm{C}$, from $-10^{\circ} \mathrm{C}$ to $100^{\circ} \mathrm{C}$, were tested.

3.3 An original testing bench was designed and set up to test closed nickel-titanium coil springs in induced tension under controlled conditions of forces and temperatures reproducing as closely as possible the intraoral environment (Figure 2).

Forces delivered by the same coil springs in traction from $0 \mathrm{~mm}$ to $10 \mathrm{~mm}$ were measured at different oral temperatures $[3,4,5,6]: 35^{\circ} \mathrm{C}$ ( 2 coil springs per batch), $5^{\circ} \mathrm{C}$ ( 2 coil springs per batch), $\mathbf{5 5}^{\circ} \mathrm{C}$ ( 2 coil springs per batch).

The displacement rate was $\pm 5 \mathrm{~mm} /$ minute.

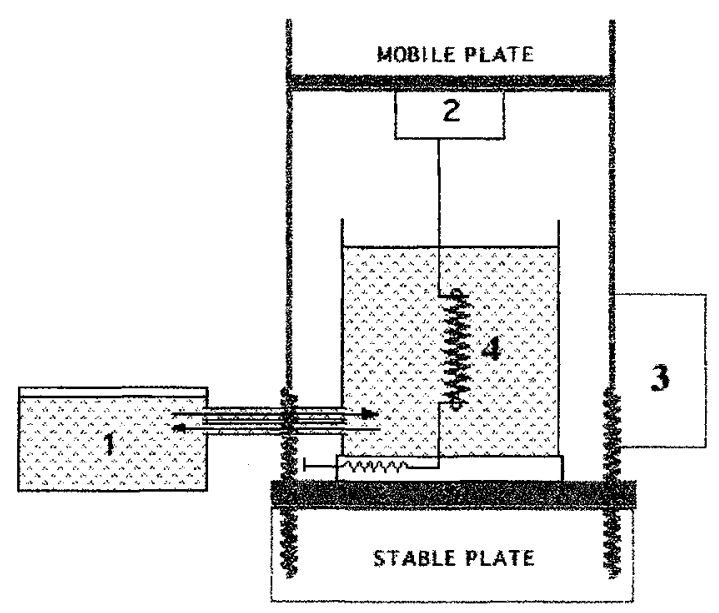

Figure 2: Diagrammatic representation of testing bench. Thermostatic water heater (1), strength sensor (2), extensometer (3), sample (4) 


\section{RESULTS}

\subsection{Scanning Electron Microscopy}

All springs consist of approximately $57 \%$ Nickel, $43 \%$ Titanium. No Copper was detected. (Figure 3 )
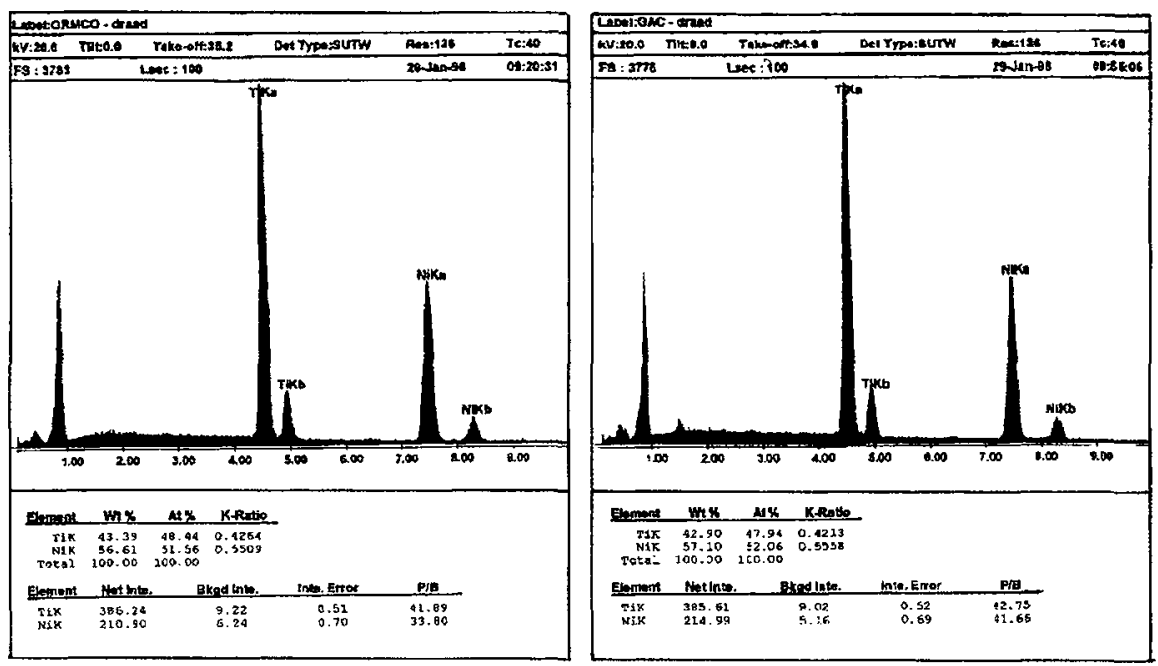

Figure 3 : Composition of the coils

\subsection{DIFFERENTIAL SCANNING CALORIMETRY}

DSC shows that structural changes with cooling and heating of closed Nickel-Titanium coil spring Alloys involve three phases: austenite, R-phase and martensite (Figure 4).
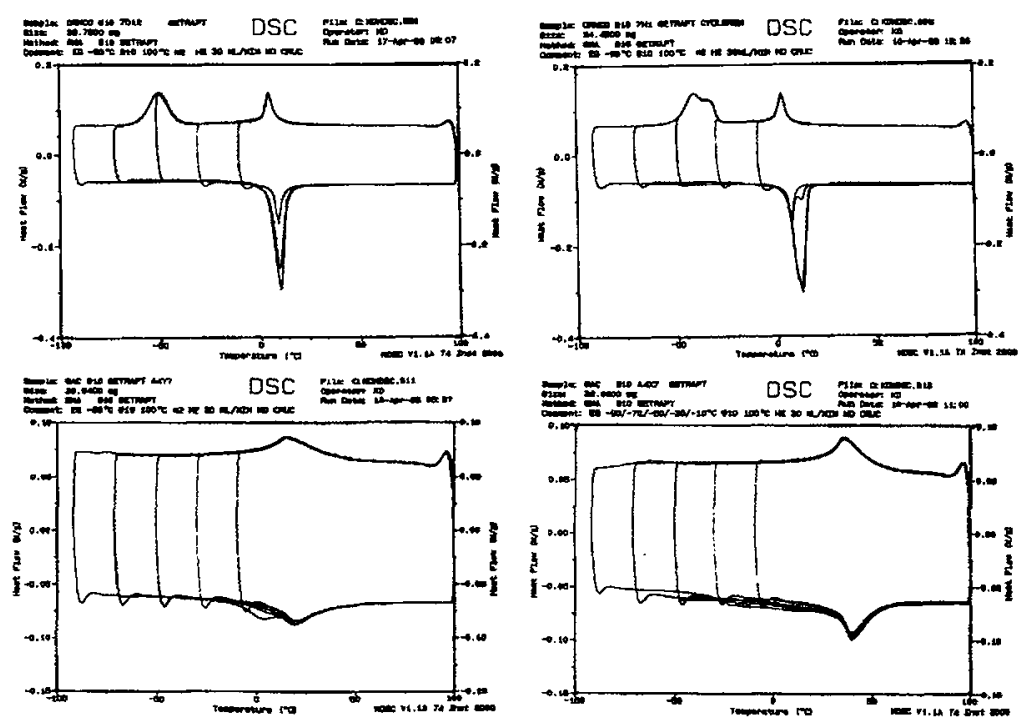

Figure 4 : Differential Scanning Calorimetry (D.S.C.) regulated by helium of ORMCO $7 \mathrm{D} 12, \mathrm{ORMCO}^{\circ} \mathrm{7H1}$, $\mathrm{GAC}^{8} \mathrm{~A} 4 \mathrm{Y} 7, \mathrm{GAC}^{\otimes} \mathrm{A} 4 \mathrm{X} 7$ in between $-90^{\circ} \mathrm{C}$ and $100^{\circ} \mathrm{C}$ 
For ORMCO ${ }^{*}$ on cooling two peaks were observed, but on heating only a single peak could be seen. Incomplete thermal cycles revealed the R-phase on heating.

For $\mathrm{GAC}^{\circ}$ on cooling one peak and two peaks on heating were observed. Incomplete thermal cycles revealed the martensitic phase on cooling. It appeared beetween $-30^{\circ} \mathrm{C}$ and $-50^{\circ} \mathrm{C}$.

Table 1: Mean transformation temperatures for each batch, during cooling and heating.

\begin{tabular}{|c|c|c|c|c|}
\hline COOLING & \multicolumn{4}{|c|}{ TEMPERATURES $\left({ }^{\circ} \mathrm{C}\right)$} \\
\hline MANUFACTURER / BATCH & $\mathrm{R}_{\mathrm{s}}^{\mathrm{A}}$ & $R_{f}^{A}$ & $M_{s}^{R}$ & $M^{R}$ \\
\hline $\mathrm{ORMCO}^{\Phi} / 7 \mathrm{Hl}$ & $+6^{\circ}$ & $-2^{\circ}$ & $-29^{\circ}$ & $-51^{\circ}$ \\
\hline $\mathrm{ORMCO}^{\infty} / 7 \mathrm{D} 12$ & $+9^{\circ}$ & $0^{\circ}$ & $-42^{\circ}$ & $-61^{\circ}$ \\
\hline $\mathrm{GAC}^{-1 / \mathrm{A} 4 \mathrm{Y} 7}$ & $+40^{\circ}$ & $-4^{\circ}$ & $\begin{array}{c}\text { between } \\
-30 \text { and }-50^{\circ}\end{array}$ & $\leq-100^{\circ}$ \\
\hline $\mathrm{GAC}^{8} / \mathrm{A} 4 \mathrm{X} 7$ & $+53^{\circ}$ & $+24^{\circ}$ & $\begin{array}{c}\text { between } \\
-30 \text { and }-50^{\circ}\end{array}$ & $\leq-100^{\circ}$ \\
\hline
\end{tabular}

\begin{tabular}{|c|c|c|c|c|}
\hline HEATING & \multicolumn{4}{|c|}{ TEMPERATURES $\left({ }^{\circ} \mathrm{C}\right)$} \\
\hline MANUFACTURER / BATCH & $\mathrm{R}_{\mathrm{S}}^{\mathrm{M}}$ & $\mathrm{R}_{\mathrm{f}}^{\mathrm{M}}$ & $\mathrm{A}_{\mathrm{s}}^{\mathrm{R}}$ & $A_{f}^{R}$ \\
\hline $\mathrm{ORMCO}^{\infty} / 7 \mathrm{H} 1$ & $+5^{\circ}$ & $?$ & $+5^{\circ}$ & $+18^{\circ}$ \\
\hline $\mathrm{ORMCO}^{\infty} / 7 \mathrm{D} 12$ & $+3^{\circ}$ & $?$ & $+9^{\circ}$ & $+15^{\circ}$ \\
\hline $\mathrm{GAC}^{\otimes} / \mathrm{A} 4 \mathrm{Y} 7$ & $-12^{\circ}$ & $?$ & $?$ & $+38^{\circ}$ \\
\hline $\mathrm{GAC}^{2} / \mathrm{A} 4 \mathrm{X} 7$ & $-28^{\circ}$ & $?$ & $+34^{\circ}$ & $+54^{\circ}$ \\
\hline
\end{tabular}

Transformation temperatures as established by D.S.C.:

- were identical for coil springs drawn from the same batch of each company.

- varied from one batch to the other of the same company (Table 1).

- varied from one company to the other (Table 1).

\subsection{TRACTION TESTS AT $35^{\circ} \mathrm{C}$}

All coil springs show superelastic properties when they are elongated (Figure 5).

Forces delivered by closed coil spring drawn from the same batch of each company were identical.

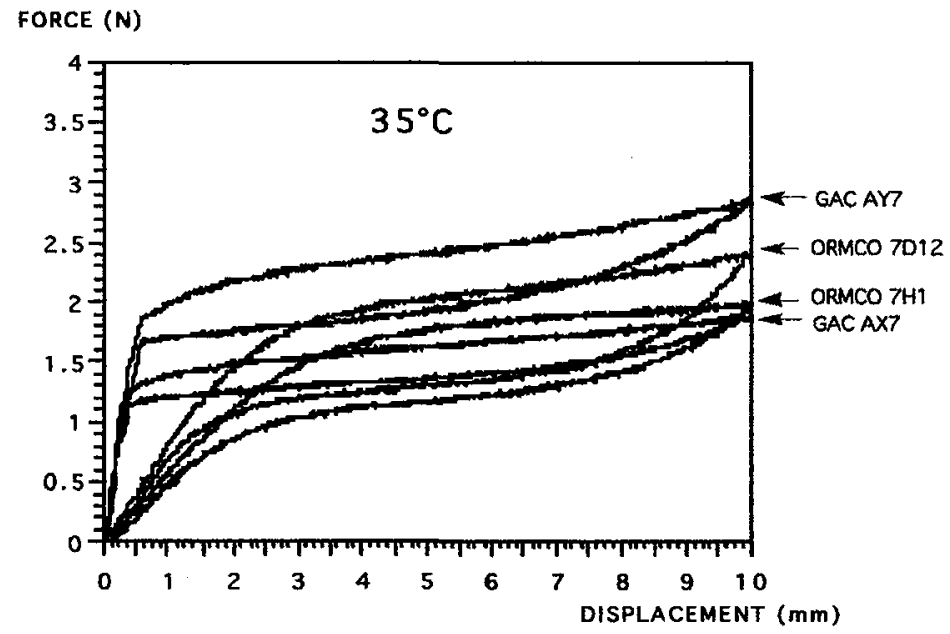

Figure 5: Stress-strain in a uniaxial tensile test at $\mathrm{T}=35^{\circ} \mathrm{C}$ 
Forces delivered varied not only from one manufacturer to the other, but they also varied from one batch to the other of each supplier. This was particularly obvious for one of the two companies (Figure 5).

\subsection{TRACTION TESTS AT $5^{\circ} \mathrm{C} \mathrm{AND} 55^{\circ} \mathrm{C}$}

Delivered forces varied considerably with temperature: they increased and decreased proportionally to temperature (Figure 6 and 7).

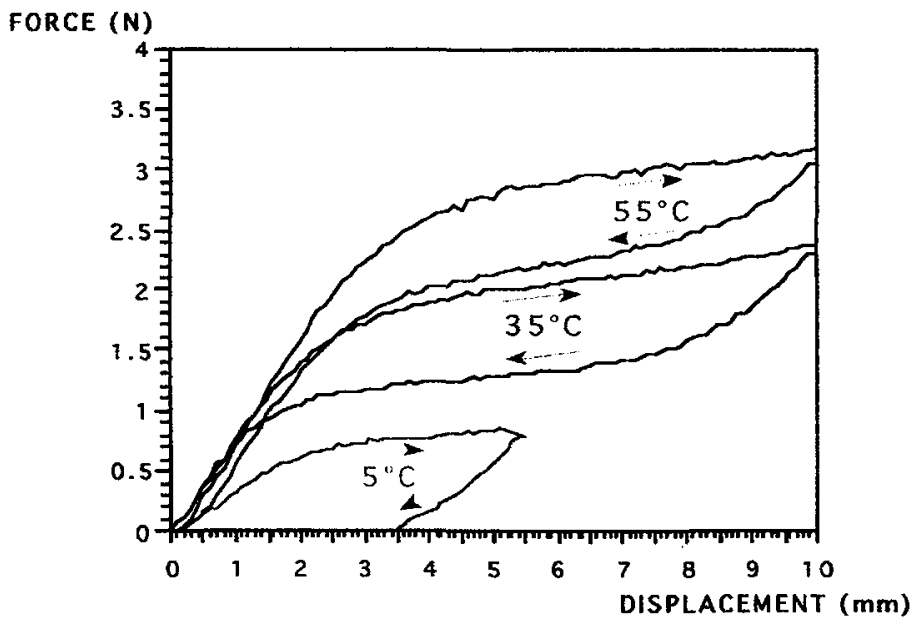

Figure 6: The effect of temperature on stress-strain in a uniaxial tensile test for ORMCO ${ }^{*}$ closed coil spring

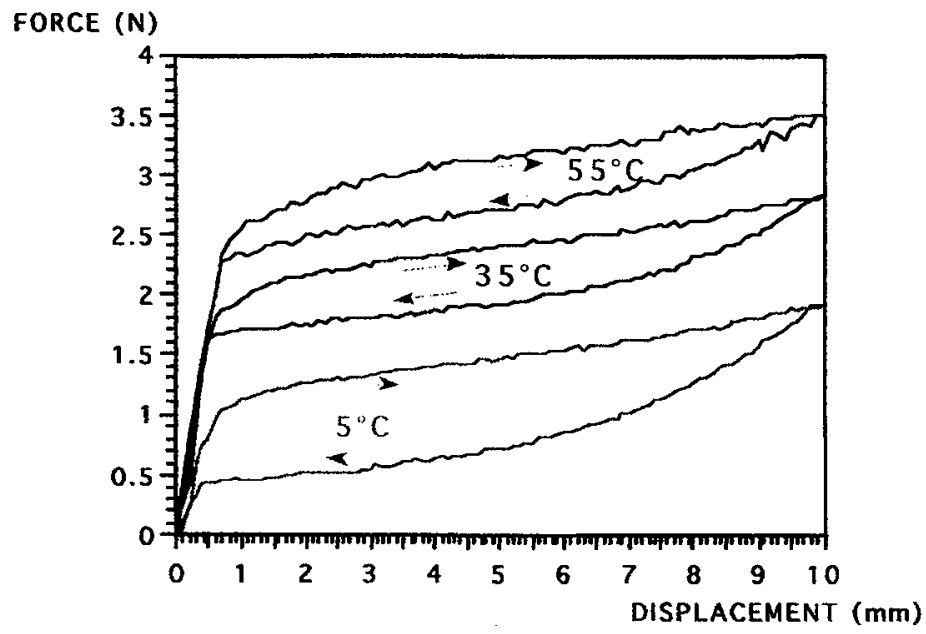

Figure 7: The effect of temperature on stress-strain in a uniaxial tensile test for $\mathrm{GAC}^{\natural}$ closed coil spring 


\section{DISCUSSION}

\subsection{At $35^{\circ} \mathrm{C}$}

$\mathrm{ORMCQ}^{\circ} \mathrm{Ni}-\mathrm{Ti}$ alloy is in the Austenitic phase because $35^{\circ} \mathrm{C}$ is higher than $A_{f}^{R}$.

The shape of the traction curve is explained by the simultaneous appearance of $R$ and Martensitic phases.

GAC Ni-Ti alloy is in the Austenitic and the R phases because $35^{\circ} \mathrm{C}$ is lower than $A^{R}$.

$0.5 \mathrm{~mm}$ of loading activates the conversion of the Austenitic phase into the Martensitic phase ( $R$ phase does not intervene).

\subsection{At $55^{\circ} \mathrm{C}$}

All coil springs tested required higher loading in order to generate conversion into $\mathrm{R}$ or Martensitic phases. This reflect the increased range of temperature between $55^{\circ} \mathrm{C}$ and $R_{s}$ s. An increased force intensity appears.

\subsection{At $5^{\circ} \mathrm{C}$}

$\mathrm{ORMCQ}^{\oplus} \mathrm{Ni}$-Ti alloy is in Austenitic and $\mathrm{R}$ phases.

Since the temperature is closer to $M_{S}$, force intensity is lower. When unloading is completed, a permanent deformation persists since $M^{R}$ is closer to $5^{\circ} \mathrm{C}$ (Martensitic phase is stable at this temperature).

GAC Ni-Ti alloy is mainly in $\mathrm{R}$ phase.

Forces are lower at $5^{\circ} \mathrm{C}$ than at $35^{\circ} \mathrm{C}$. There is no permanent deformation, because the Martensitic phase is not stable.

\section{CONCLUSION}

Slow deactivation shown by the plateaus of tension curves is of true value to the orthodontist: it means that continuous forces are delivered, a very desirable feature. It nevertheless requires precise knowledge of forces intensities readily obtained with a dynamometer.

Delivered forces vary proportionally to temperature.

Optimal clinical use of Nickel-Titanium coil springs would be much obtained by greater stability of their properties in the range of buccal temperature.

Consistency at loading, which activates conversion of the austenitic phase into the martensitic phase, should be expected from all closed Nickel-Titanium coil springs.

\section{References}

1. F. Miura, M. Mogi, Y.Ohura, M. Karibe, Am. J. Orthod. Dentofacial Orthop. 94 (2) , 58 (1988).

2. L. Jordan, M.P. Filleul, R. Portier, Rev. Orthop. Dento Faciale 31 (2), 199 (1997).

3. D.S. Gowers, D. Nash, H.M. Ellis, J. Occup. Environ. Med. 37 (11), 1259 (1995).

4. A. Volchansky, P. Cleaton-Jones, P.G. Wright, L.P.Fatti, J. Dent. 13 (4), 323 (1985).

5. G. Airoldi, G. Riva, M. Vanelli, V. Filippi, G. Garattini, Am. J. Orthod. Dentofacial Orthop. 112

(1), 58 (1997).

6. P.M. Michailesco, J. Marciano, A.R. Grieve, M.J. Abadie, J. Prosthet. Dent. - 73 (2) , 214 (1995). 